\title{
Geogrid Reinforced Granular Pad Foundation Resting on Loose and Soft Soils, Hamilton Harbour, Ontario
}

\author{
C. Alston ${ }^{1}\left(\mathbb{D} \cdot\right.$ D. K. Lowry ${ }^{2}$ A. Lister $^{3}$
}

Received: 21 April 2015/Accepted: 1 June 2015/Published online: 7 July 2015

(C) Springer International Publishing AG 2015

\begin{abstract}
The waterfront quays in Hamilton Harbour have been constructed by placing upfill within a perimeter steel sheet pile bulkhead. The fill materials are believed to consist of dredged material loosely placed on the original harbour bed, within the enclosure. The quayside had been used for general dock activities, including stockpiling discharged ships' cargoes. Recently, two $31 \mathrm{~m}$ diameter liquid storage tanks have been constructed on the site; the stored liquid applies a load of $120 \mathrm{kPa}$ to the ground surface. Based on borehole data developed in an initial geotechnical investigation of the site, it was recommended that the tank loadings be supported on either stone columns or end bearing pile foundations. The cost of these foundation systems was prohibitive to the development. Additional fieldwork consisting of three soundings with a Marchetti flat plate dilatometer was carried out to better define the geotechnical properties of the soil profile. Using these data, a foundation design was prepared which consisted of construction of a geogrid reinforced granular pad. Post construction monitoring of settlement of the tank foundation shows that settlement of the foundation has been within tolerable limits.
\end{abstract}

Keywords Soft soils - In situ testing by flat dilatometer . Settlement - Foundation design with geogrid reinforcement

C. Alston

colin_agc@bellnet.ca

1 Alston Geotechnical Consultants Inc., 102 Senator Reesor's Drive, Markham, ON L3P 3E5, Canada

2 Armtec, 370 Speedvale Avenue West, Guelph N1H 7M7, Canada

3 TenCate Mirafi, 2113 Keith Close, Burlington, ON L7M 3H8, Canada

\section{Introduction}

The site development consisted of the design and construction of two $31 \mathrm{~m}$ diameter liquid storage tanks at the Emerald Street Slip, which lies on the south side of Hamilton Harbour, Ontario, Canada (Fig. 1). At this location the land has been reclaimed from the Harbour by construction of a steel sheet pile bulkhead enclosure which was then infilled on the landward side to provide a level surface for cargo handling and storage. It is believed that the infill used to raise the grade in the slip area consisted of harbour bed dredged material, which was loosely placed on the harbour bed within the perimeter bulkhead.

In the vicinity of the development site, various buildings and storage tanks have been constructed. However, the study site is situated on a previously undeveloped area of the Slip. Anecdotal evidence indicates that some of the current development site had been used previously for storage of unloaded ships cargoes consisting of construction aggregates in conical piles, which were more than $10 \mathrm{~m}$ high. The perimeter of such storage stockpiles was believed to lie between the north and south limits of the development site, which resulted in the soil profile beneath the southerly portion of the site area having experienced consolidation under such applied loads.

A previous geotechnical investigation of the site area was undertaken prior to undertaking the described investigation and design works. That study consisted of advancing six conventional sampled boreholes to depths of up to $26 \mathrm{~m}$. Sampling and in situ testing was carried out in those boreholes by the standard penetration test method. The results of that test program illustrated the following typical soil profile:

- Ground surface to $0.5 \mathrm{~m}$; pavement structure. 
Fig. 1 Site plan, Emerald Street Slip Hamilton Harbour

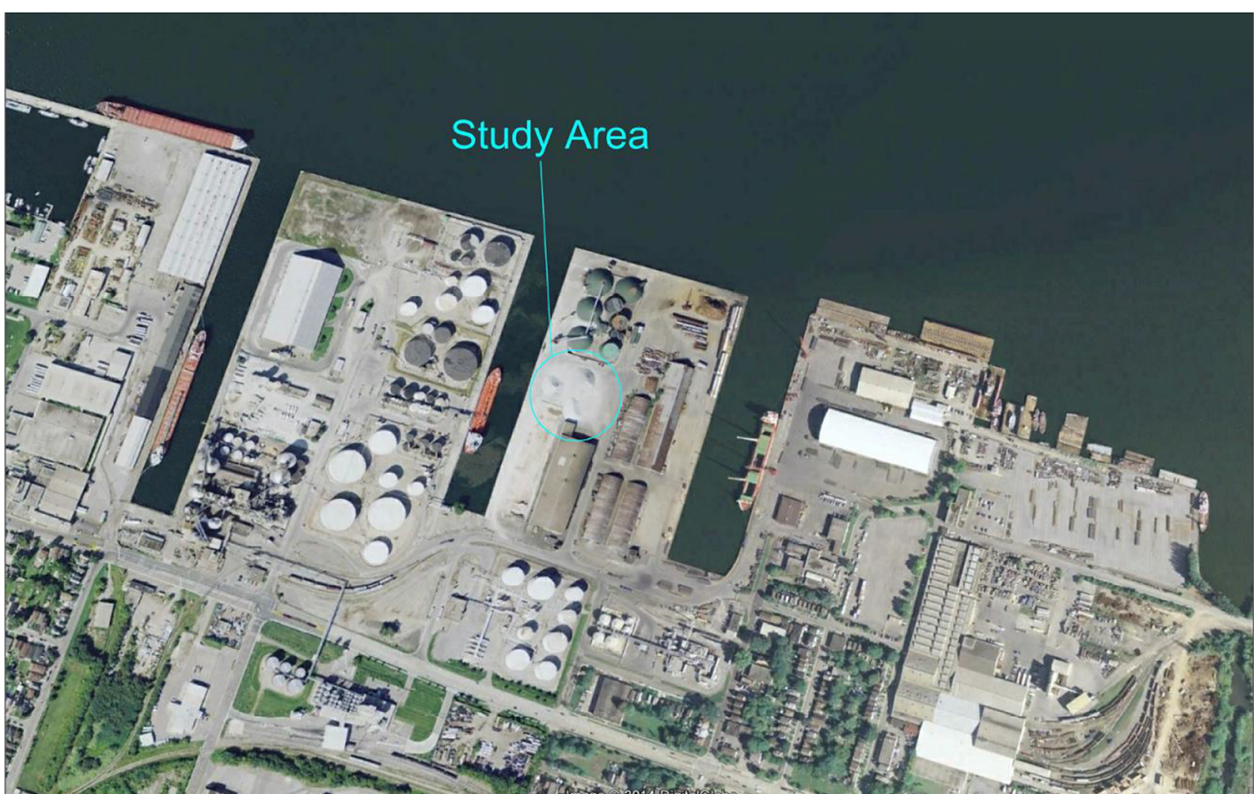

Fig. 2 Exploration location plan

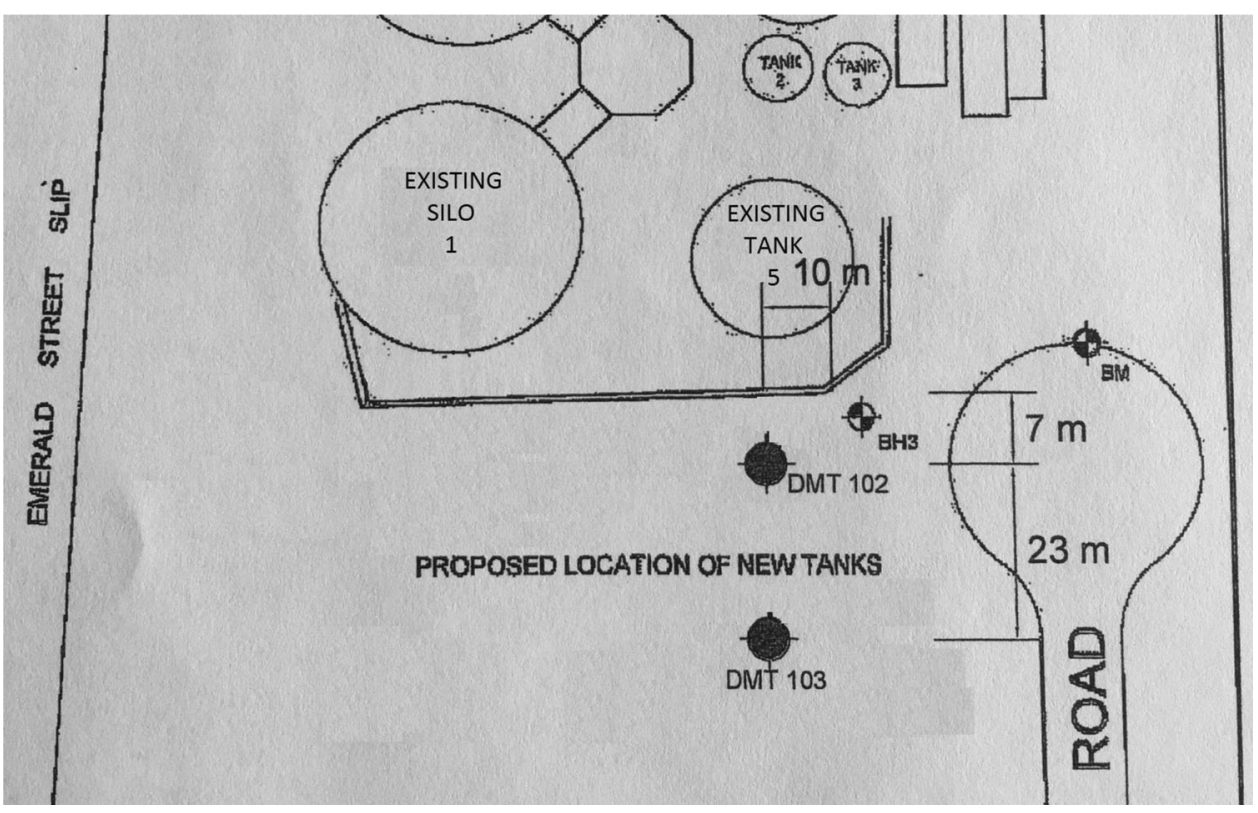

- $\quad 0.5$ to 7-12 m; Fill, mostly consisting of silt to sand with zones of silty clay. The layer is considered in two sections, with an approximate $2 \mathrm{~m}$ thick upper sub-unit of loose to compact sand and gravel with some ash lying on very loose to loose silt to silty sand. The soil condition was interpreted from standard penetration test $N$ values of 8-55 blows/300 mm recorded in the upper sub-unit of the fill, and $N$ values of 1-5 blows/300 mm in the lower portion of the layer.

- 7-12 to $24 \mathrm{~m}$; soft to firm becoming stiff silty clay, soil consistency represented by $N$ values of 1-34 blows/
$300 \mathrm{~mm}$, more commonly in the range of 3-15 blows/ $300 \mathrm{~mm}$;

- 24-26 m, dense to very dense clayey silt and sand, condition represented by an $N$ value of more than 50 blows/300 mm;

- $26 \mathrm{~m}$ shale bedrock.

In one of the boreholes, a $4 \mathrm{~m}$ thick layer of compressed peat was found to be sandwiched between the base of the fill and the underlying sequence of mineral soil deposits; $N$ values of 7 and 8 blows $/ 300 \mathrm{~mm}$ were measured in this 
Fig. 3 Borehole log

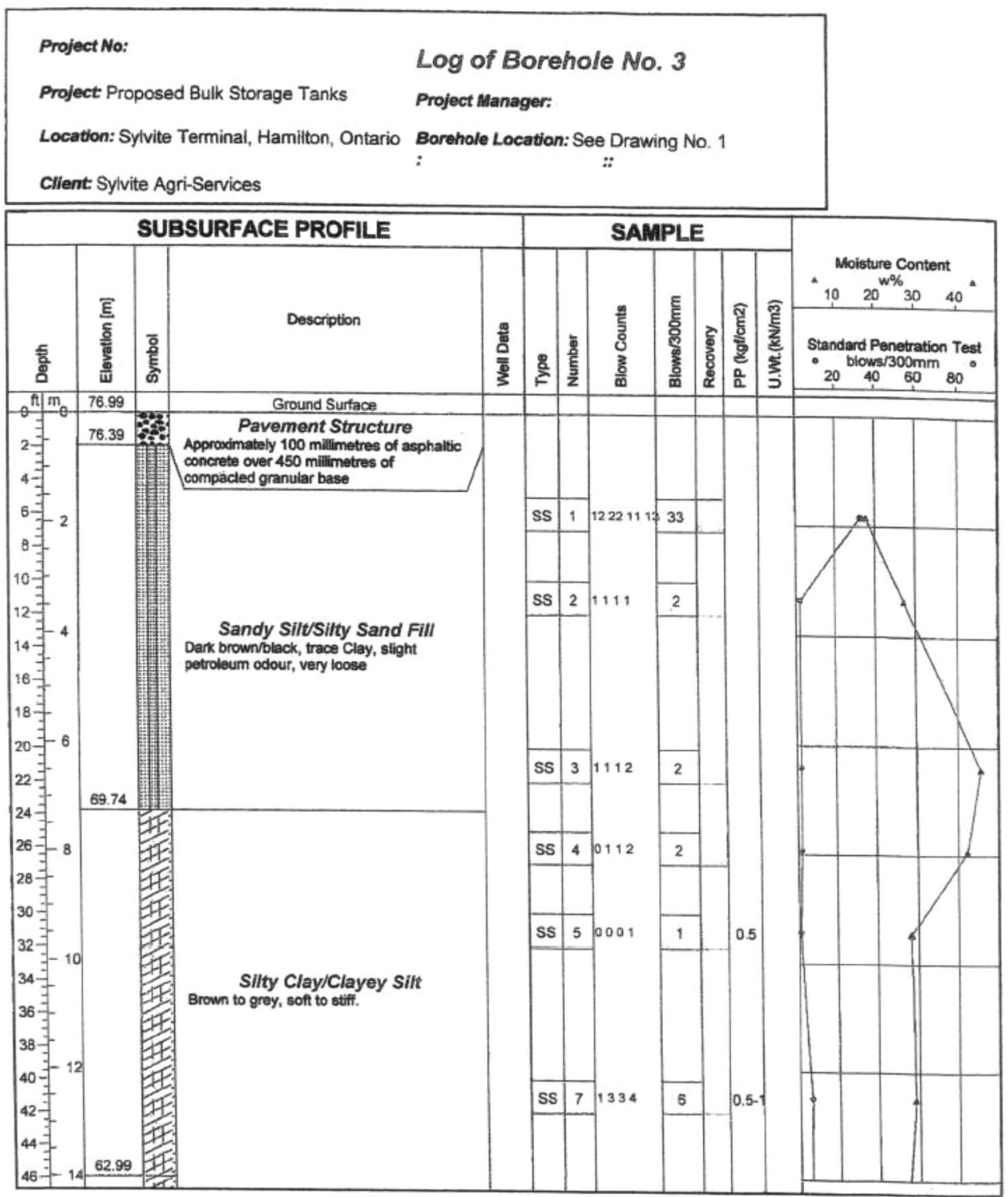

soil lens. A plan showing the locations of geotechnical explorations is given in Fig. 2. A copy of a $\log$ sheet for a representative borehole is given in Fig. 3. On the basis of the determined soil profile and interpreted soil condition data from the sampled borehole investigation, the original geotechnical engineer concluded that the soil profile underlying the site could not support the tank loads and that each of the two storage tanks should be founded on an array of end bearing piles which would be embedded in the very dense basal soil stratum or on bedrock. An alternative recommendation was given that the condition of the underlying soils could be improved sufficiently to support the tanks by installation of a set of stone columns. The estimated cost of providing such a foundation was approximately $\$ 500,000.00$, above the cost of a conventional shallow foundation, which compromised the financial viability of the project. Therefore, the owner determined that an independent review of the subsurface data be carried out with a view to developing a design which provides foundation support at shallow depth in the soil profile.

Some details of this case study were previously presented by Alston et al. [1].

\section{Geotechnical Investigation of In Situ Soil Properties}

It is well known that steel storage tanks are settlement tolerant [2-4]. Also, as noted in Sect. 1, anecdotal evidence indicated that previously, the southerly portion of the site had been loaded with stockpiles of aggregate materials to a height of up to about $10 \mathrm{~m}$. Thus, past performance of the ground in the general area of the site had shown that the subsurface profile was able to sustain significant surface 


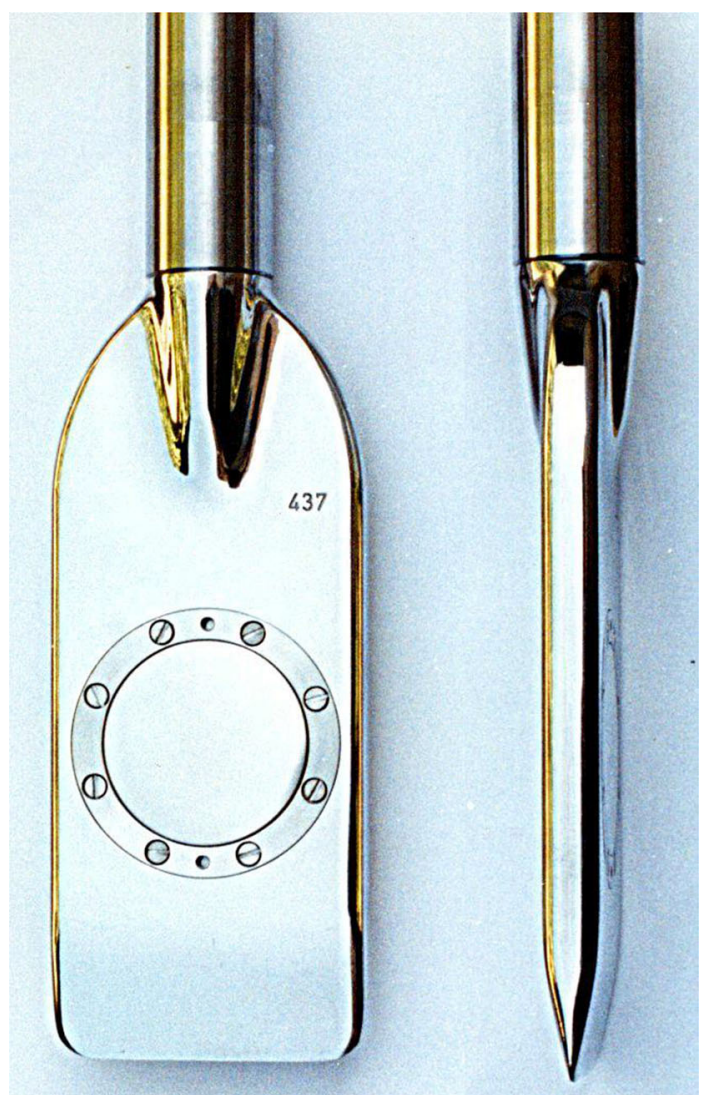

Fig. 4 Illustration of test blade Marchetti flat plate dilatometer

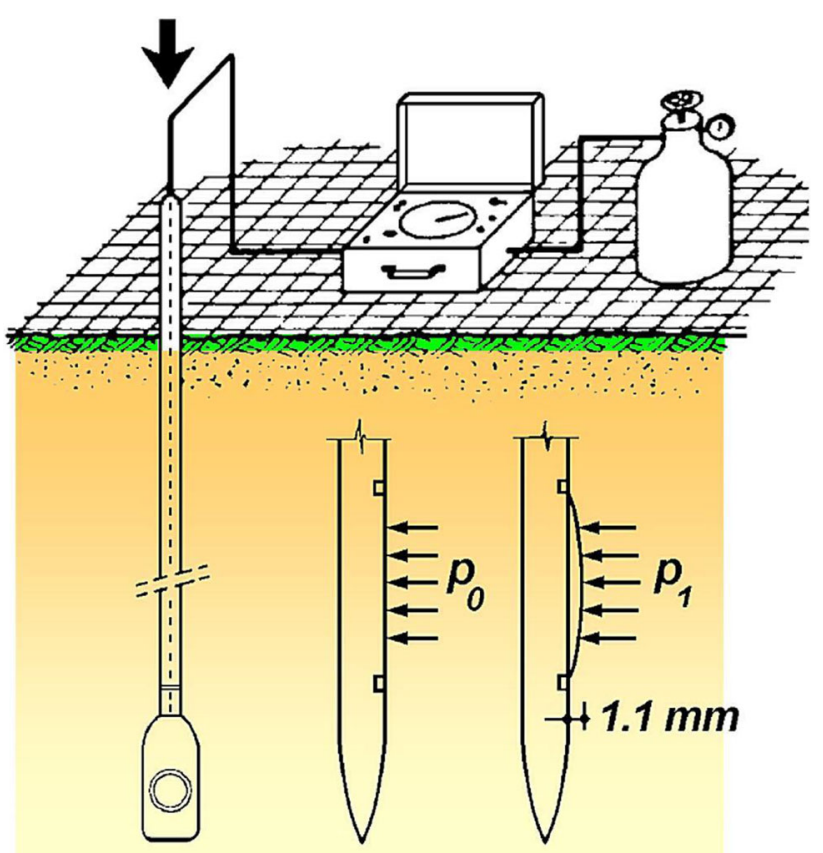

Fig. 5 Illustration of field arrangement Marchetti flat plate dilatometer loadings without experiencing a catastrophic shear failure. On this basis, an additional geotechnical investigation of the site [5] was undertaken to better define the in situ properties of the soil profile. The second phase of geotechnical work was designed to complement the available borehole data with a more sophisticated program of in situ testing. This work unit consisted of advancing three soundings using a Marchetti flat plate dilatometer (DMT) to provide interpreted measures of in situ soil properties [6]. A picture of a dilatometer blade is shown in Fig. 4 [7] and a diagrammatic illustration of the test arrangement is shown in Fig. 5 [7]. The soundings were advanced under the northerly part of the development site in which the anecdotal evidence indicated that no previous significant loading had been applied to the site area, as well as in the more central and southern portions of the site which are believed to have been previously subject to significant loading by aggregate stockpiles. The results of the northerly sounding (DMT 102) and the southerly sounding (DMT 103) are given in Figs. 6 and 7, respectively. Reference to the results of the soundings illustrates the interpreted behavioural character of the overlying fill materials as well as the inferred engineering properties of the various soil materials which were contacted in the soundings. Reference to the reported in situ test results also illustrates the beneficial effect of previous loading of the site by stockpiled aggregates on soil parameters such as undrained shear strength and constrained modulus. Summaries of the soil parameters selected for stability analysis and settlement predictions are shown in Table 1.

Published literature $[8,9]$ shows that good confidence can be placed on the results of DMT soundings with regard to settlement predictions.

\section{Geotechnical Design}

The results of the subsurface investigations of the site showed that the geotechnical design of surface supported structures would be primarily controlled by the properties of the relatively weak surficial layer of fill and the upper soft to firm zone of the underlying silty clay soil deposit. These soil layers could be expected to experience significant consolidation as a result of load application. The shear strength characteristics of the respective soil layers limit the intensity of foundation load which can be applied to these layers to a modest level, unless the soil materials were to be improved or mechanical appurtenances designed to increase tensile strength were included in foundation design.

In order to assess the feasibility of adopting a design based on a tank base resting on grade and shallow foundations to support the tank wall loads, an estimate of 
Fig. 6 Flat dilatometer sounding 102 results
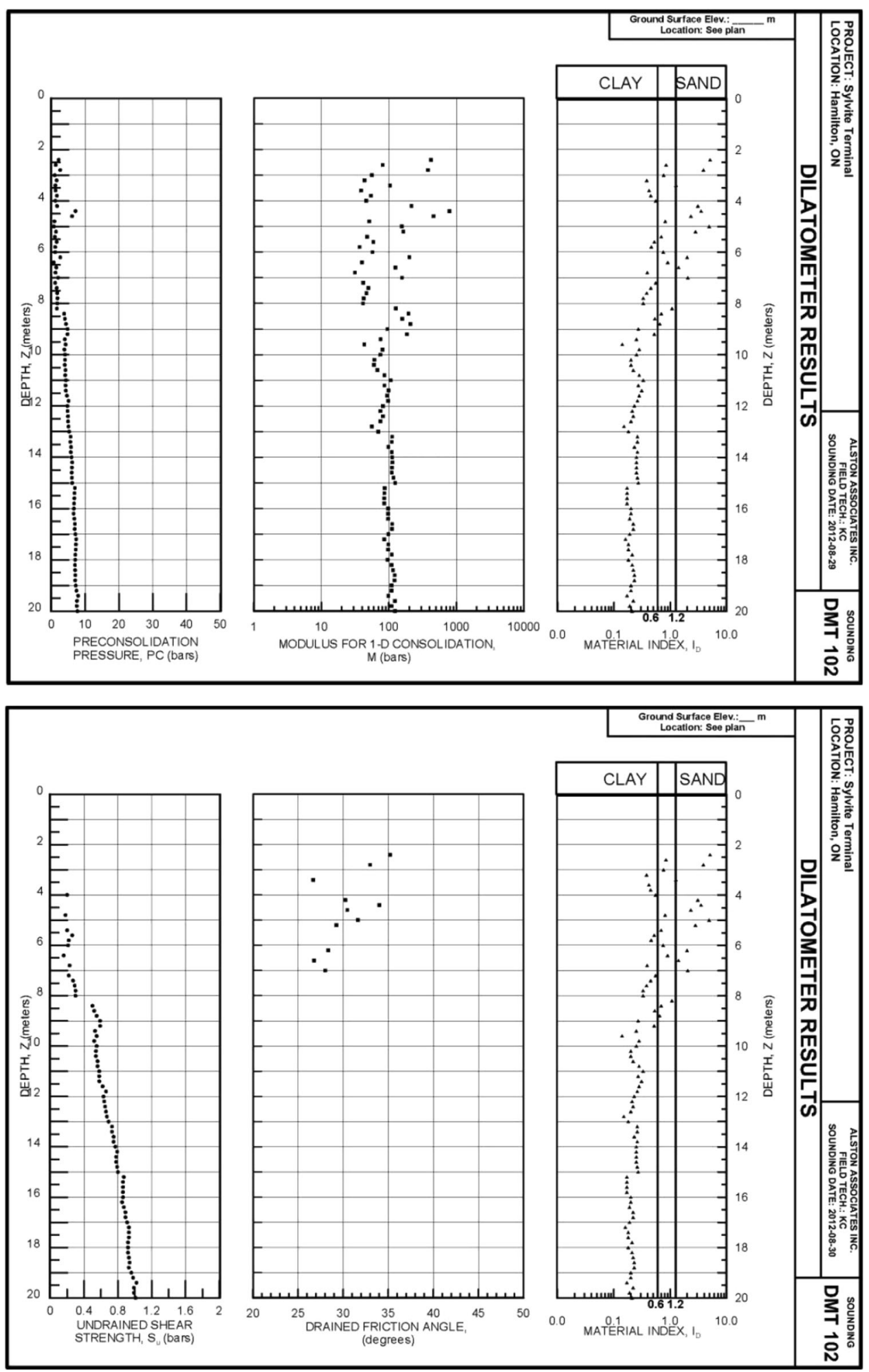

probable settlement was made to determine if this could meet the project's operational criteria. Analysis was carried out using the GEO5 program "Settlement", verified by hand calculations. The analysis of the probable consolidation settlement of loaded tank foundations was carried out using the values of constrained (deformation) modulus of the soil materials which were interpreted from the DMT results. The analysis gave estimated settlements of about $55 \mathrm{~mm}$ at the south (probably preloaded) limit of the tanks, $130 \mathrm{~mm}$ at the tank centre and about $80 \mathrm{~mm}$ at the northern 
Fig. 7 Flat dilatometer sounding 103 results
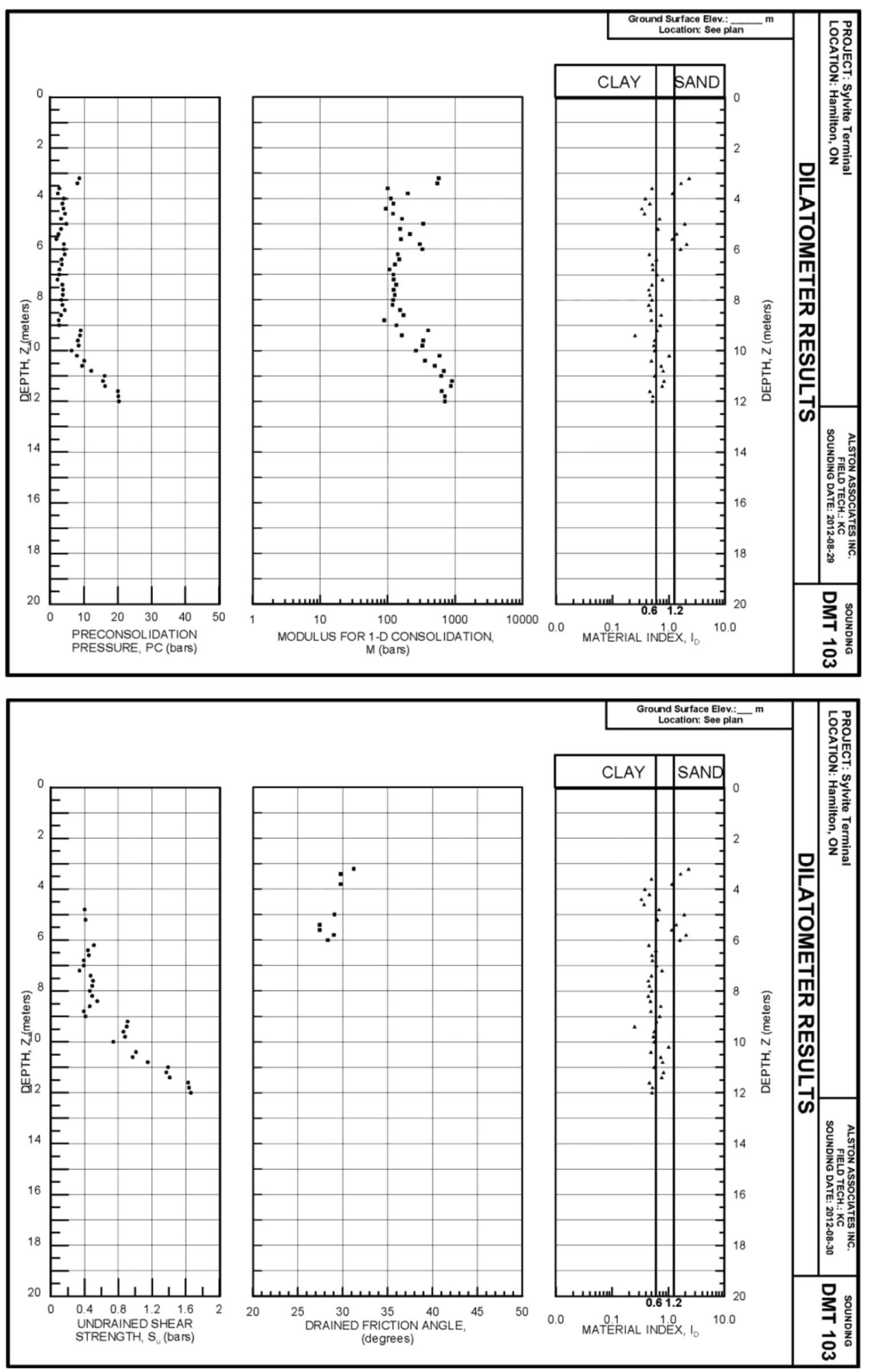

(unloaded) limit of the tank footprints. These values of settlement are within the criteria given in the referenced technical literature and were confirmed as acceptable with the Owner for the project in hand. A graphical summary of the results of the settlement analysis is given in Fig. 8 .
The values of settlement generated by the computer program were verified by hand calculation for the northern limit of the tank wall. The interpreted values of overconsolidation ratio from DMT information are generally less than 2 in the upper soil units and increase to more than 4 
Table 1 Geotechnical properties of soil units

\begin{tabular}{lcllllll}
\hline Soil unit & $\begin{array}{l}\text { Approximate } \\
\text { depth range } \\
(\text { south })(\mathrm{m})\end{array}$ & $\begin{array}{l}\text { Approximate } \\
\text { depth range } \\
(\text { north })(\mathrm{m})\end{array}$ & $\begin{array}{l}\text { Angle of } \\
\text { internal } \\
\text { friction }\left(^{\circ}\right)\end{array}$ & $\begin{array}{l}\text { Undrained shear } \\
\text { strength (south) } \\
(\mathrm{kPa})\end{array}$ & $\begin{array}{l}\text { Undrained shear } \\
\text { strength (north) } \\
(\mathrm{kPa})\end{array}$ & $\begin{array}{l}\text { Constrained } \\
\text { modulus } \\
(\text { south) }(\mathrm{MPa})\end{array}$ & $\begin{array}{l}\text { Constrained } \\
\text { modulus } \\
(\mathrm{north})(\mathrm{MPa})\end{array}$ \\
\hline Silty clay fill & - & $0-4$ & - & - & 20 & - & 4.5 \\
Silt and sand fill & $0-9$ & $4-5.5$ & 27 & - & 28 & - & 20 \\
Firm silty clay & - & $5.5-10$ & - & - & 70 & 10 & 10 \\
Stiff silty clay & $9+$ & $10+$ & - & 70 & & \\
\hline
\end{tabular}

below a depth of $8.5 \mathrm{~m}$; on that basis it was expected that little consolidation would occur below that depth. The estimated settlement at the check position was as shown in Table 2 .

This gives an accumulated consolidation settlement of $72 \mathrm{~mm}$, which is comparable with, but less conservative than, the computed value of $80 \mathrm{~mm}$.

The settlement criteria being met, the design challenge was to include tensile reinforcement in the design which would upgrade the support characteristics of the underlying relatively weak soils to secure the foundations against shear failure in the foundation soils with adequate factors of safety, to meet contemporary standards.

The borehole and sounding data show that the near surface fill materials underlying the site consist of a variety of dominantly granular material (sand, gravel, ash, cinders present in varying proportions). The results of grain size distribution tests carried out on samples of the upper subunit of the fill show that these materials could be selectively excavated and mostly re-used and engineered to provide a granular pad with consistent soil properties to support tank foundations, provided that the pad is suitably reinforced. Analysis showed that inclusion of geosynthetic reinforcement in the engineered granular fill pad would add sufficient tensile strength to the fill pad to improve the design factors of safety with respect to both local and global stability, to satisfy conventional foundation design criteria. The selected reinforcement consisted of including two layers of polyester geogrid each with an ultimate tensile strength of $68 \mathrm{kN} / \mathrm{m}$ in the primary direction (Mirafi $5 \mathrm{XT}$ ) in the engineered fill pad; the main direction of the selected uniaxial geogrid was to be laid radially towards the centre of the tank, and perpendicular to the tank wall. The lower level of geogrid was positioned at the base of the fill pad and the second layer $300 \mathrm{~mm}$ above the base. The design thickness of the engineered granular base is $1.5 \mathrm{~m}$. The adopted analytical method to assess global stability was based on the assumption that a beneficial horizontal reinforcement force can be included in a simplified Bishop analysis [10-12]. A summary of the results of the global stability analyses which show that the critical failure surface, with respect to global stability, is given in Fig. 9. This figure also illustrates the differences in the properties of the soil profile between the south and north sides of the tanks. The factor of safety of the critical failure surface with respect to global stability for the selected foundation design was determined to be 1.54 .

The beneficial effect of the geogrid reinforcement on increasing the bearing capacity of the granular pad with regard to the perimeter wall foundations was evaluated using methodology given by FHWA [13]. This was adequate to meet design criteria.

\section{Construction of the Foundation}

Construction of the foundation consisted of removing the existing site surface layer of asphaltic concrete pavement as well as the immediately underlying zones of the upper fill layer to a depth of $1.5 \mathrm{~m}$ below the base of the tank foundation. The excavation phase was followed by dense compaction of the material exposed in the base of the excavation to its maximum practical density, which was carried out using a smooth drum roller with a static load of 10 tonnes under full time engineering control. Satisfactory compaction of the base was assured by visual engineering inspection and in situ testing with a hand operated static penetrometer. The base layer of geogrid reinforcement was laid in a radial pattern on the floor of the excavation beneath the footprint of the tanks and extending outside the footprint of the wall footing for a width of $3 \mathrm{~m}$. A plan of the layout of the geogrid sheets is given in Fig. 10, and an image of the emplaced geogrid is given in Fig. 11. A $300 \mathrm{~mm}$ thick layer of the local, excavated granular fill adjudged suitable by the Engineer's on-site representative was laid on the base geogrid and compacted to $100 \%$ of the material's standard Proctor maximum dry density. The second layer of the geogrid was laid on the emplaced lift of compacted fill to the same pattern and dimensions as the lower sheets of reinforcement. Above the reinforcement, the grade was raised to the design elevations using local suitable granular fill which was compacted to $100 \%$ of material's standard Proctor maximum dry density.

Construction of the reinforced concrete tank wall foundations and tank base proceeded on top of the geogrid reinforced, densely compacted pad of engineered fill. 
Fig. 8 Results of settlement analysis

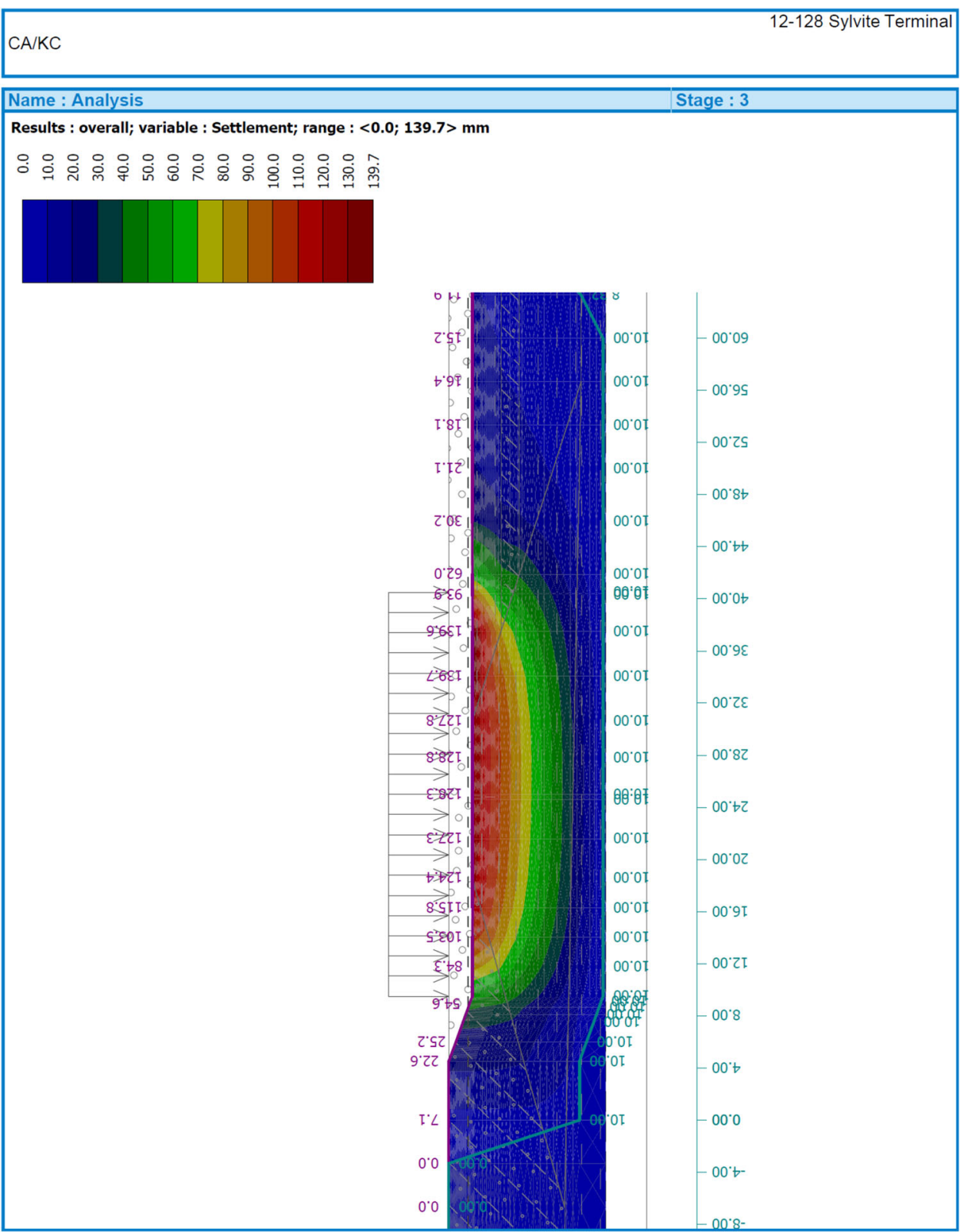

[GEO5 - Settlement | version 5.14.90 | hardware key 8221 / 1 | Alston Associates Inc | Copyright O 2012 Fine spol s s ro. All Rights Reserved | wmw finesoftware eu]

\begin{tabular}{llcc}
\hline Depth range & $\begin{array}{l}\text { Average increase } \\
\text { in vertical stress }(\mathrm{kPa})\end{array}$ & $\begin{array}{l}\text { Constrained } \\
\text { modulus }(\mathrm{MPa})\end{array}$ & $\begin{array}{l}\text { Consolidation } \\
\text { settlement }(\mathrm{mm})\end{array}$ \\
\hline $0-4$ & 60 & 4.5 & 53 \\
$4-5.5$ & 55 & 20.0 & 4 \\
$5.5-8.5$ & 50 & 10.0 & 15 \\
\hline
\end{tabular}

Table 2 Estimated settlement in design calculations foundation was approximately $55 \mathrm{~mm}$, and about $85 \mathrm{~mm}$ at the northern limit. The difference between the two estimated settlement values is attributed to the result of the effects of previous loading of the site by aggregate stockpiles. Actual settlement values were measured on the 


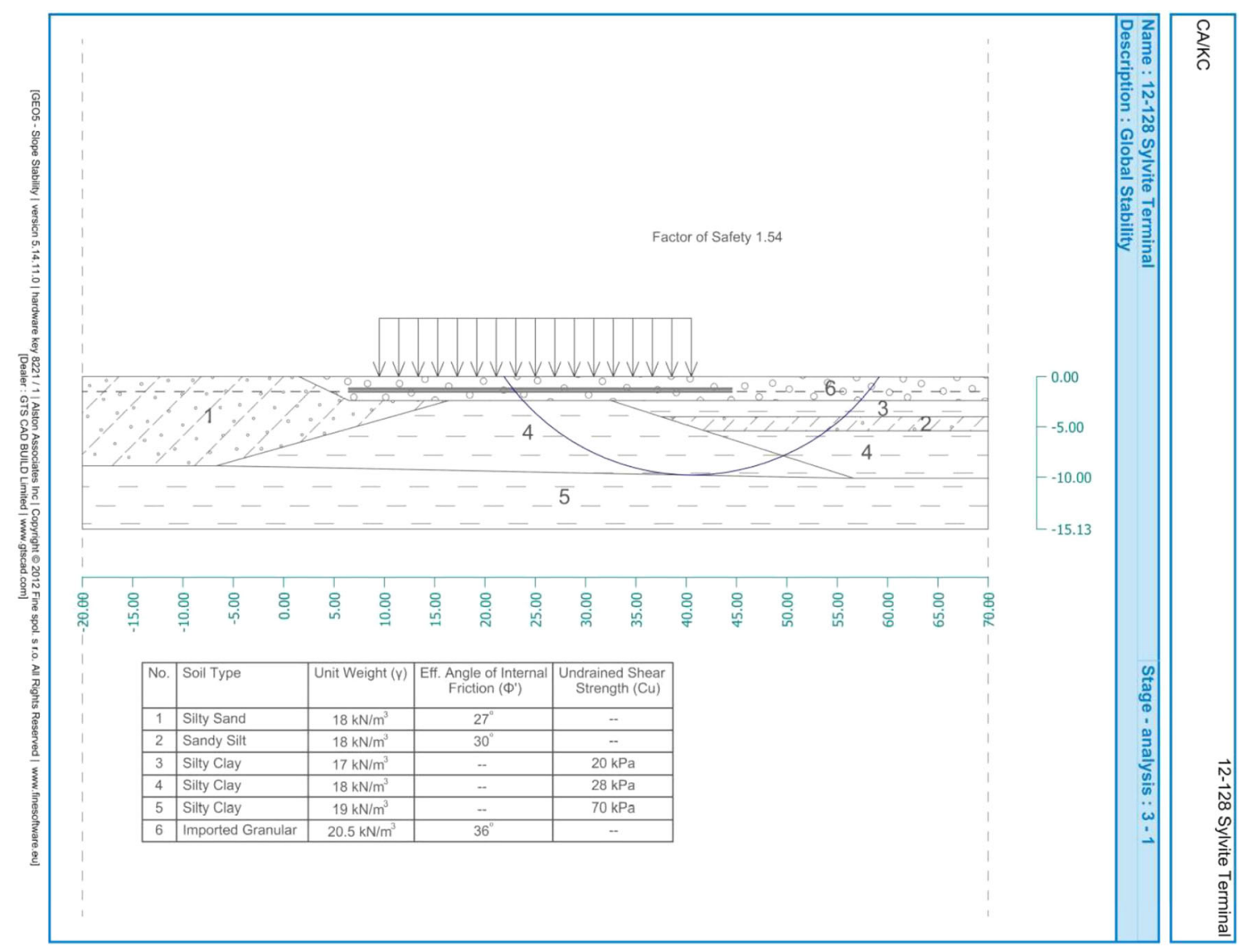

Fig. 9 Global stability analysis

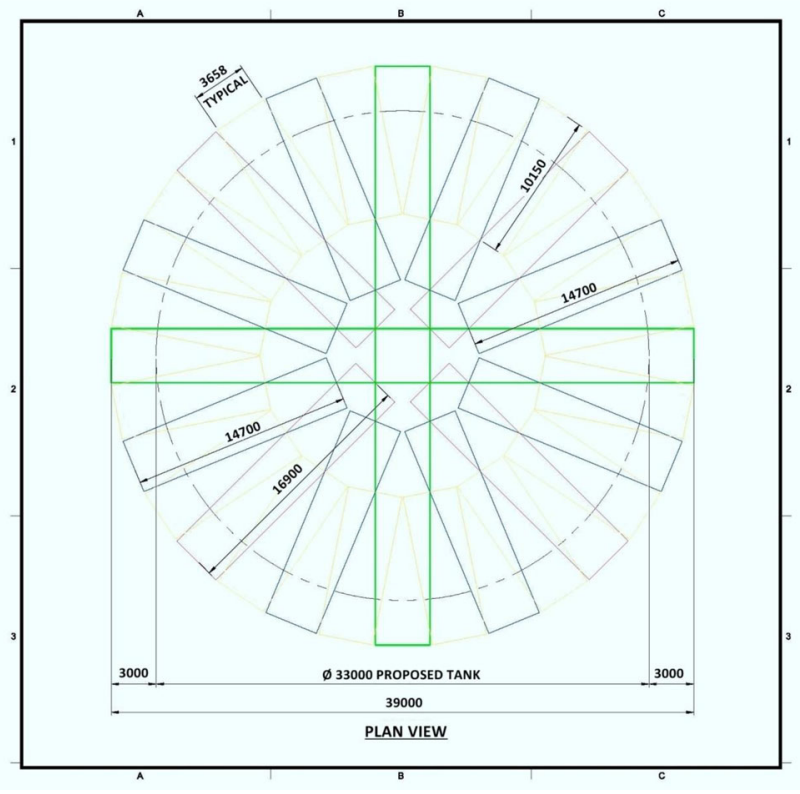

Fig. 10 Plan view of geogrid layout foundation wall of one of the tanks and those results are given in Table 3.

The measured values show settlements of about 70 and $80 \%$ of the theoretical predictions for the north and south sides of the tank, respectively. The underlying soils consist of loose (fill) or soft to firm (silty clay) materials and some ongoing creep settlement is expected. The actual settlement of the wall foundations falls within a reasonable proximity of the predicted values.

The cost premium of the adopted reinforced soil pad foundation system constructed on the site compared with a conventional footing foundation under the tank walls and a granular base beneath the tank floor was about $\$ 200,000.00$ for the two tank foundations. The estimated cost premium of a foundation comprising either a system of end bearing piles or stone columns was more than $\$ 500,000.00$ above the cost of a footing foundation. Thus, the selection of the reinforced pad foundation resulted in a cost saving of about $60 \%$ compared to the initially recommended foundation system.

An image of the completed tanks are given in Fig. 12. 


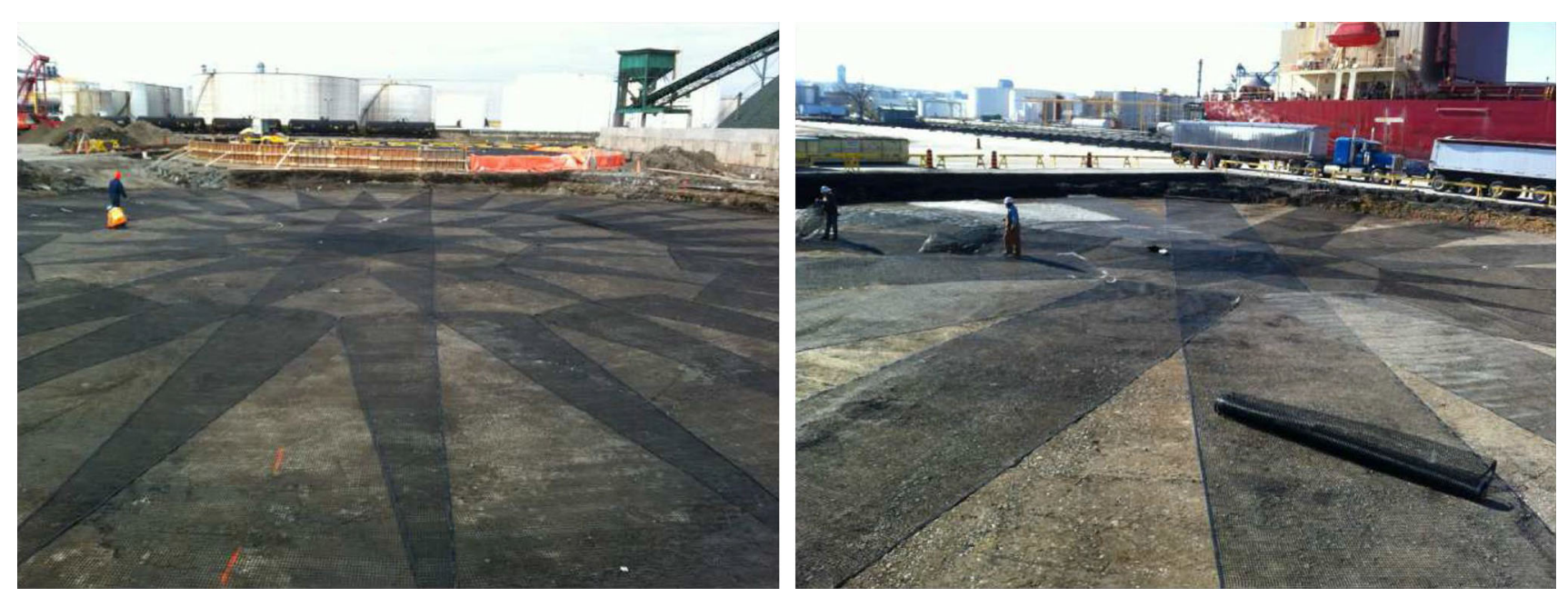

Fig. 11 Geogrid reinforcement on excavation base

Table 3 Settlement of perimeter ring beam foundation

\begin{tabular}{llllll}
\hline Time from first load application & \multicolumn{2}{l}{ Predicted settlement } & & \multicolumn{2}{l}{ Measured settlement } \\
\cline { 2 - 3 } $\begin{array}{l}\text { North side } \\
(\mathrm{mm})\end{array}$ & $\begin{array}{l}\text { South side } \\
(\mathrm{mm})\end{array}$ & & $\begin{array}{l}\text { North side } \\
(\mathrm{mm})\end{array}$ & $\begin{array}{l}\text { South side } \\
(\mathrm{mm})\end{array}$ \\
\hline 1 week & - & - & 9 & 9 \\
1 month & - & - & & 25 & 23 \\
1 year & 80 & 50 & & 54 & 41 \\
\hline
\end{tabular}

Fig. 12 Completed tanks

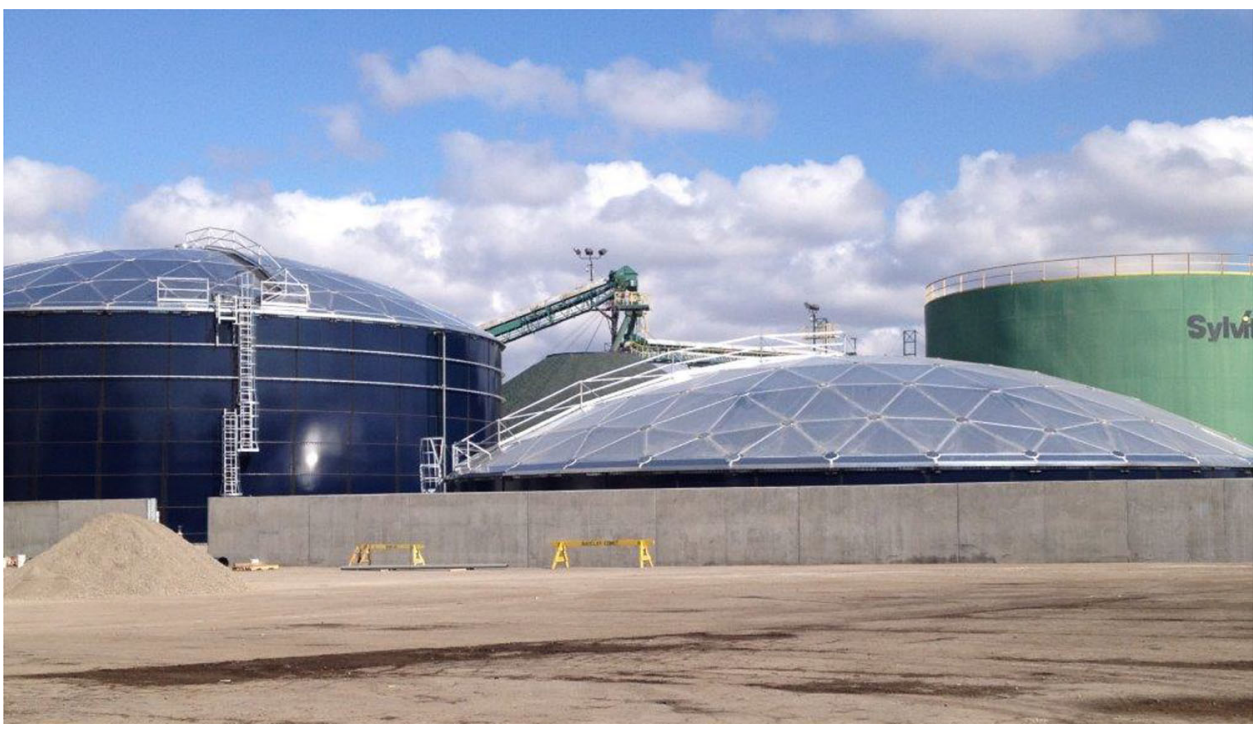

\section{Conclusions}

(1) Characterization of strength and deformation parameters of the supporting soil strata by an in situ test method (Marchetti flat dilatometer) has resulted in good characterization of the soil properties.
(2) Construction of an engineered pad of reinforced granular fill above layers of relatively weak, compressible fill and native soils resulted in the foundation experiencing only moderate differential settlement, which is well within tolerable limits.

(3) Design carried out using conventional limit equilibrium methods which account for the beneficial effect 
of geosynthetic reinforcement, and using conventional one dimensional consolidation theory are shown to adequately describe the site and result in a foundation performance which is satisfactory in service.

(4) The adoption of a foundation design utilizing the tensile strength of geogrid reinforcement enabled a cost savings of about $\$ 300,000.00$ on a previously estimated cost premium of about $\$ 500,000.00$ for a foundation supported by either end bearing piles or stone columns.

Acknowledgments The authors wish to thank the facility owner, Sylvite, and their General Contractor, Barclay Construction who supported the development of a non-traditional approach to foundation design and construction for the project. Barclay Construction particularly assisted and cooperated with the design team in all aspects of making this project successful.

\section{References}

1. Alston C., Lowry D.K., Lister A. (2015) Design and performance of geogrid reinforced foundation for storage tanks resting on loose, thick fill, Hamilton Harbour, Ontario. In: IFAI geosynthetics conference, Portland, Oregon
2. US Army Corps of Engineers (1999) Engineering and design, settlement analysis, Table 2-3, Engineering Manual 1110-1-1904

3. Rosenberg P, Journeaux NL (1992) Settlement limitations for cylindrical steel storage tanks. Can Geotech J 19:232-238

4. Akhaven AA (2009) Settlement criteria for steel oil storage tanks. EJGE 13:1-9

5. Alston Associates Inc. (2012) Geotechnical investigation study, proposed tank developments. Sylvite Group of Companies, Emerald Street Slip, Hamilton

6. Marchetti S (1980) In situ tests by flat dilatometer. J ASCE 106(GT3):299-321

7. Marchetti S (2015) Personal communication, illustrations of Flat Plate Dilatometer

8. Technical Committee TC16 (2001) The DMT in soil investigations. A report by ISSMGE TC16

9. Mondaco P, Totani G, Celebrese M (2006) DMT-predicted versus observed settlements: a review of the available experience. In: Proceedings on 2 nd international conference on the flat dilatometer, Washington, pp. 244-252

10. Holtz RD (1990) Design and construction of geosynthetically reinforced embankments on very soft soils. State of the art report, performance of reinforced soil structures. British Geotechnical Society, p. 391-402

11. Holtz RD, Christopher BR, Berg RR (1998) Geosynthetic design and construction guidelines, FHWA HI-95-038

12. Jones CJFP (1996) Earth reinforcement and soil structures. Thomas Telford, London

13. Abu-Farsakh, MY and Chen Q (2008) Use of reinforced soil foundations (RSF) to support shallow foundation. Report No. FHWA/LA. 08/424, Louisiana Transportation Research Centre, Baton Rouge, LA, USA 